\title{
Annual variability of heavy metal content in Svalbard reindeer faeces as a result of dietary preferences
}

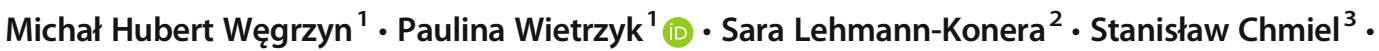 \\ Beata Cykowska-Marzencka ${ }^{4}$ (iD $\cdot$ Żaneta Polkowska ${ }^{2}$
}

Received: 11 April 2018 / Accepted: 16 October 2018 / Published online: 30 October 2018

(C) The Author(s) 2018

\begin{abstract}
During both winter and summer, Svalbard reindeer selectively feed on different types of vegetation that are not only a source of nutritional value, but also a place of heavy metal accumulation. In the present study, the content of cadmium, chromium, copper, iron, lead, nickel, manganese, and zinc in reindeer excrement was measured. The main aims were to determine the seasonal content of several heavy metals in Svalbard reindeer faeces, and to compare their values in terms of dietary preferences during the year. Summer and winter reindeer excrement was gathered along a designated linear transect running through Bolterdalen and the vegetation described on $1 \mathrm{~m}^{2}$ plots. All of the analysed heavy metals were detected in the reindeer faeces and this fact seems to be connected with the incomplete content of these elements in an animal's tissue after forage digestion. Analysis showed differences between summer and winter excrement in terms of concentrations of cadmium, chromium, iron, and nickel, but no differences were found for the other four elements analysed (manganese, lead, zinc, and copper). However, concentrations of heavy metals in faeces are rather low in comparison with both the levels in the vegetation that may be grazed by reindeer and in reindeer tissue.
\end{abstract}

Keywords Rangifer tarandus platyrhynchus $\cdot$ Contamination $\cdot$ Pollution $\cdot$ Vegetation

\section{Introduction}

Disturbances to wildlife caused by human activity and industrial development pressures are an important environmental

Responsible editor: Philippe Garrigues

Electronic supplementary material The online version of this article (https://doi.org/10.1007/s11356-018-3479-8) contains supplementary material, which is available to authorized users.

Paulina Wietrzyk

paulina.wietrzyk@doctoral.uj.edu.pl

1 Prof. Z. Czeppe Department of Polar Research and Documentation, Institute of Botany, Jagiellonian University, Gronostajowa 3, 30-387 Cracow, Poland

2 Department of Analytical Chemistry, Faculty of Chemistry, Gdańsk University of Technology, 11/12 Narutowicza St., 80-233 Gdańsk, Poland

3 Department of Hydrology and Climatology, Faculty of Earth Sciences and Spatial Management, Maria Curie-Skłodowska University in Lublin, 2cd Kraśnicka St., 20-718 Lublin, Poland

4 Laboratory of Bryology, W. Szafer Institute of Botany, Polish Academy of Sciences, Lubicz 46, 31-512 Cracow, Poland issue in Arctic ecosystems. Although polar ecosystems experience less direct impact from human activity compared with other areas, all their abiotic and biotic components receive contaminants due to the long-distance transport of toxic substances from lower latitudes (e.g. Weinbruch et al. 2012). Anthropogenic pollutants, including heavy metals, may accumulate in ecosystems, both directly via atmospheric deposition (Nriagu 1989, 1979) and indirectly through the influence of windblown dust, marine aerosols, and water from melting snow and glaciers (Drbal et al. 1992; Steinnes 1995; Aastrup et al. 2000; Samecka-Cymerman et al. 2011; Ruman et al. 2012; Weinbruch et al. 2012).

One of the priority issues of the Arctic Monitoring Assessment Programme is to monitor and assess heavy metals. According to AMAP (2005), most heavy metals are released into the environment from anthropogenic sources, while $\mathrm{Mn}$ and $\mathrm{Cr}$ mostly originate from natural sources. Regardless of the origin of heavy metals, they may have a crucial impact on the Arctic environment due to their toxic effects on living organisms. In Arctic terrestrial ecosystems, the majority of heavy metals accumulate in vegetation: vascular plants (Jóźwik 2000), bryophytes (Samecka-Cymerman et al. 2011) and lichens (Garty 2001; Wegrzyn et al. 2013, 
2016; Wojtuń et al. 2013), which are also foraged by Svalbard reindeer (Rangifer tarandus platyrhynchus). The AMAP report (2005) classified heavy metals into elements that are biologically essential (e.g. $\mathrm{Cr}, \mathrm{Cu}, \mathrm{Ni}, \mathrm{Fe}, \mathrm{Mn}, \mathrm{Zn}$ ) or nonessential (e.g. $\mathrm{Cd}, \mathrm{Pb}$ ) for a living organism. According to Clarkson (1986), the first group of elements is toxic only in excess and organisms have developed mechanisms for regulating their levels. The metals in the second group are more likely to have toxic effects on an organism than biologically essential metals; for example, the tolerable content in air-dried forage for domestic animals was estimated to be 500 $1000 \mathrm{mg} \mathrm{kg}^{1}$ for $\mathrm{Zn}, 0.5 \mathrm{mg} \mathrm{kg}^{1}$ for Cd, 25-80 mg kg${ }^{1}$ for $\mathrm{Cu}$ and $30 \mathrm{mg} \mathrm{kg}^{1}$ for $\mathrm{Pb}$ (National Research Council 1980; Stoltz and Greger 2002).

According to Environmental Monitoring of Svalbard and Jan Mayer (http://www.mosj.no), the total population of Svalbard reindeer is extremely difficult to determine, but in 2015, the local population was estimated to be as high as 1315 in the valley of Adventdalen alone. Furthermore, it was reported that in 2016, a total of 235 reindeer were shot, representing only c. $2.5-5 \%$ of the Svalbard population, and therefore did not result in any significant decline. The raw materials obtained from reindeer primarily serve the needs of human consumption; consequently, those who eat reindeer meat can be considered another link in the trophic chain, as they are exposed to the accumulation of anthropogenic contaminants in their tissue.

The accumulation of contaminants in vegetation, and later in animals (herbivores and carnivores), contributes to the circulation of harmful elements and compounds in Arctic terrestrial ecosystems (Hallanger et al. 2011; Wegrzyn et al. 2016). Trophic chains in polar areas consist of a relatively small number of species that are associated with a range of different interactions. Thus, the presence of pollutants in the Arctic environment may even lead to ecological imbalance in the ecosystem (Koivurova 2005). According to Simões and Zagorodnov (2001), Svalbard is one of the areas in the Arctic most affected by anthropogenic pollution due to atmospheric circulation.

The Svalbard reindeer subspecies that inhabits the archipelago is the only ruminant that grazes the tundra vegetation all year round. Because of their high population, which is due to a lack of natural enemies, reindeer occupy all areas of Svalbard not covered by glaciers. The local reindeer populations are considered non-migratory, as a result of which they consume vegetation within a relatively small area (Bjørkvoll et al. 2009; Hansen et al. 2010). During the short, three-month vegetation period, Svalbard reindeer have to eat enough forage to survive and build additional reserves of energy for the winter season (Bjørkvoll et al. 2009; Reimers 1982; Tyler 1986). However, the long winter usually results in the premature depletion of body reserves and a constant search for food under the snow layer (Bjørkvoll et al. 2009; Tyler 1986). Because of specific climate conditions of the archipelago, the diet of Svalbard reindeer is divided into a summer diet, dominated by the green parts and flowers of vascular plants and graminoids, and a winter diet, consisting of cryptogams and woody parts of dwarf-shrubs, which are the only source of food available to reindeer after removing the snow cover (Bjørkvoll et al. 2009; Ekern and Kildemo 1987; Staaland et al. 1993; Wegrzyn et al. 2013). Due to its specific composition of long-living vegetation, the winter diet seems to consist of vegetation characterised by an extended period of heavy metal accumulation (Austrheim et al. 2005; Sancho et al. 2007), the lichens, bryophytes and woody parts of vegetation being exposed to heavy metal accumulation over many years due to fact that they are not annual vegetation. It is therefore assumed that winter forage significantly contributes to the elemental content of reindeer.

The main aim of the present study was to determine the seasonal differences in the contents of selected heavy metals measured in Svalbard reindeer faeces, and to compare these values between the summer and winter periods in reference to reindeer dietary preferences. We set a hypothesis that assumed that contents of heavy metals in summer excrement will be lower than those in winter excrement.

\section{Material and methods}

\section{Study area and data sampling}

Fieldwork was carried out in the summer season of 2015 in Bolterdalen, a glacial valley located in Nordenskiöld Land in central Spitsbergen (Fig. 1) c. $6 \mathrm{~km}$ in length and covering c. $7.5 \mathrm{~km}^{2}$. The valley is bordered by Bolternosa and Breinosa and enclosed by the Scott-Turnerbreen and Rieperbreen glaciers (Lyså and Lnne 2001).

Summer and winter reindeer excrement was gathered along a linear transect delimited along Bolterdalen (Figs. 1, S1) since a possible difference in shape and consistency between summer and winter excrement was noticed. For summer faeces, only fresh, moist samples were collected, and then dried. Winter faeces were characteristic pellet-shaped droppings and their age for 2014/2015 seasons was determined on the basis of their compact structures, namely no clear cavities as a result of ageing, no cover of cyanobacteria layer on their surface, their black or black-grey surfaces being shiny with no clear matt coating on faeces older than last winter. Both types of excrement were collected at the same 15 sites ( 30 samples) located between 150 and $250 \mathrm{~m}$ a.s.1. The samples were dried, packed in sealed plastic bags and transported to Poland for laboratory analyses.

To identify vegetation from the study area, $1-\mathrm{m}^{2}$ plots were designated at ten selected excrement collection sites along the transect. Within these plots, the percentage cover of vascular plants, bryophytes and lichens was determined according to the scale of Braun-Blanquet (1964). 


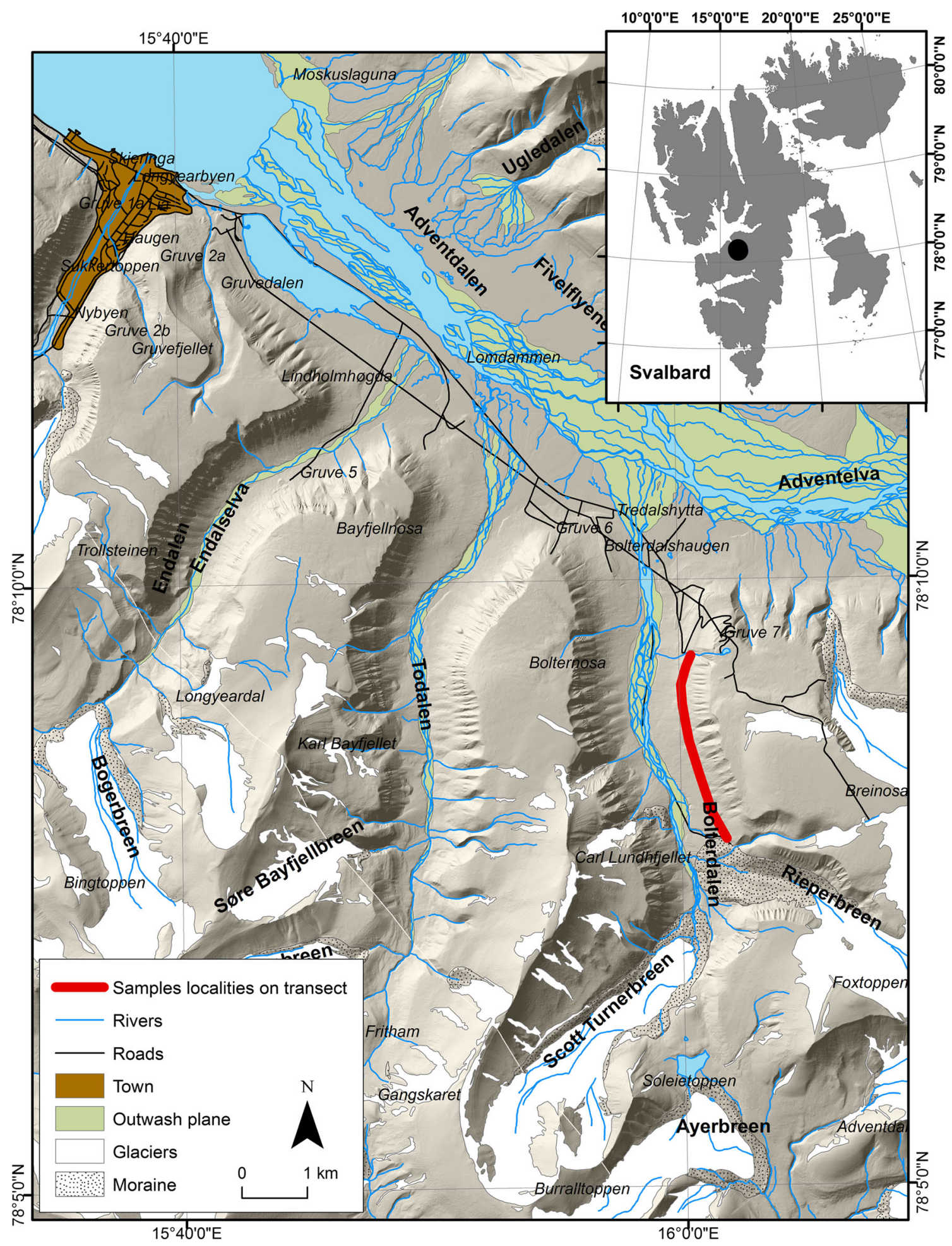

Fig. 1 Location of the study area (@ Norwegian Polar Institute 2016, www.npolar.no)

\section{Laboratory analyses}

Samples of reindeer excrement were lyophilised at $-80{ }^{\circ} \mathrm{C}$ and subsequently homogenised and sieved with a $2-\mathrm{mm}$ plastic sieve. Thereafter, $0.5 \mathrm{~g}$ of excrement samples was mineralised and extracted in $8 \mathrm{ml}$ of $65 \% \mathrm{HNO}_{3}$ (suprapur) acid using the
Microwave Digestion System (Multiwave GO of Anton Paar). The mineralisation temperature programme was as follows: a 20 min increase in temperature to $180^{\circ} \mathrm{C}$, a 10 -min hold in temperature at $180{ }^{\circ} \mathrm{C}$ and $10 \mathrm{~min}$ of cooling to $60^{\circ} \mathrm{C}$. Following the mineralisation process the samples were transferred quantitatively to $25-\mathrm{ml}$ flasks and filled with dionised water. 
Table 1 Validation parameters and technical specifications used to determine metals

\begin{tabular}{llllll}
\hline Parameter & Measurement range & LOD $^{\mathrm{a}}$ & LOQ $^{\mathrm{b}}$ & Measurement instrumentation \\
\hline Heavy metals $[\mu \mathrm{g} / \mathrm{L}]$ & $\mathrm{Cd}$ & $0.01-1000$ & 0.01 & 0.03 & Thermo Scientific XSERIES 2 ICP-MS Germany, \\
& $\mathrm{Cr}, \mathrm{Mn}, \mathrm{Ni}, \mathrm{Cu}, \mathrm{Zn}, \mathrm{Pb}$ & $0.1-1000$ & 0.10 & 0.30 & collision cell technology, cool gas flow Ar: 12 1/min, \\
& $\mathrm{Fe}$ & $1.0-1000$ & 1.00 & 3.00 & cell gas flow He/H: $5,5 \mathrm{ml} / \mathrm{min}$ \\
\hline
\end{tabular}

${ }^{\mathrm{a}}$ The limit of detection (LOD) was calculated on the basis of the standard deviation of the response

(s) and the slope of the calibration curve (b), according to the following formula: $\mathrm{LOD}=3.3(\mathrm{~s} / \mathrm{b})$

${ }^{b}$ The limit of quantitation (LOQ) was calculated on the basis of the standard deviation of the response

(s) and the slope of the calibration curve (b) according to the following formula: $\mathrm{LOQ}=10(\mathrm{~s} / \mathrm{b})$

Various groups of analyses involved the application of Mili-Q demineralised water (Mili-Q ${ }^{\circledR}$ Ultrapure Water Purification Systems, Millipore ${ }^{\circledR}$ production). Metals (cadmium, chromium, copper, iron, lead, nickel, manganese and zinc) were determined by means of ion coupled plasma mass spectrometry (Thermo Scientific XSERIES 2 ICP-MS) (Table 1). These were analysed using Standard Reference Material NIST 1643e Trace Elements in Water, and Reference Material EnviroMAT ES-L-2 CRM, ES-H-2 CRM SCP SCIENCE. Calibration of the apparatus was based on reference materials supplied by Inorganic Ventures: ANALITYK-CCS-4, CCS-6, CCS-1 and IV-ICPMS-71A.

\section{Statistical analyses}

Levene's test was performed to assess the equality of variances, while the Shapiro-Wilk test helped determine the normality of the data set. The U Mann-Whitney test was used to assess differences in heavy metal concentrations between summer and winter reindeer excrement along the transect.

\section{Results}

\section{A description of the vegetation in the study area}

A general characterisation was prepared of the vegetation along the designated transect as shown in Table S1 which lists the recorded species together with the degree of cover and the phytosociological constancy of each taxon. The vegetation is represented by mesic tundra, dominated by vascular plants (59\%), mainly dwarf shrubs, such as Dryas octopetala, Cassiope tetragona and Salix polaris; bryophytes and lichens respectively represented $16 \%$ and $20 \%$ of the cover.

In the case of bryophytes, Sanionia uncinata, Aulacomnium turgidum and Ditrichum flexicaule were present in all the plots and provided the most cover. Crustose and foliose lichens species were dominant, with Peltigera venosa, Collema ceraniscum and Ochrolechia frigida providing the main components of the biological soil crusts (BSCs). Fruticose lichens were infrequently observed, such as
Flavocetraria nivalis, a species frequently grazed by reindeer (Ziaja et al. 2016; Olech et al. 2011), but Stereocaulon alpinum, Cetrariella delisei and Cladonia macroceras provided relatively high cover values in all the plots (Table S1).

\section{Heavy metal content in reindeer excrement}

Eight of the selected heavy metals were detected in the collected reindeer faeces (Table 2, S2); a comparison of between their summer and winter elemental levels is provided in Fig. 2, significant differences confirmed by the U Mann-Whitney test as follows: $\mathrm{Cd}(\mathrm{U}=39 ; p=0.002), \mathrm{Cr}(\mathrm{U}=57 ; p=$ $0.022), \mathrm{Fe}(\mathrm{U}=56 ; p=0.02)$ and $\mathrm{Ni}(\mathrm{U}=64 ; p=0.046)$; however, there were no differences in element contents between summer and winter faeces for the following: $\mathrm{Cu}(\mathrm{U}=111 ; p=$ $0.97), \mathrm{Mn}(\mathrm{U}=79 ; p=0.17), \mathrm{Pb}(\mathrm{U}=83 ; p=0.23)$ and $\mathrm{Zn}$ $(\mathrm{U}=65 ; p=0.051)$.

\section{Discussion}

Only a few studies have focused on reindeer excrement as a subject of research (Na et al. 2015; Wang et al. 2015; Zhang et al. 2014; Zhu et al. 2015), all of which examined the presence of organic pollutants known for their carcinogenic and mutagenic properties (e.g. polychlorinated biphenyls, polybrominated biphenyl ethers, polycyclic aromatic hydrocarbons). The literature includes much less information on the metal content of reindeer kidneys (Borch-Iohnsen et al. 1996; Larter and Nagy 2000), livers (Aastrup et al. 2000; BorchIohnsen et al. 1996) or muscles (Aastrup et al. 2000). In the case of Svalbard, only Staaland et al. (1983) conducted research on the content of iron, copper, manganese, zinc, molybdenum and cobalt in reindeer excrement, but these samples were gathered directly from distal colons. Because Svalbard reindeer are considered to be non-migratory (Bjørkvoll et al. 2009; Hansen et al. 2010; Tyler and Øritsland 1989), data on the heavy metal content of their faeces may be used for noninvasive contamination monitoring purposes on a local scale.

The presence of all studied heavy metals in reindeer faeces is possibly connected with the incomplete content of these 
Table 2 The average, standard deviation, minimum and maximum values of heavy metal content $\left[\mathrm{mg} \mathrm{kg}^{-1}\right]$ in summer and winter faeces

\begin{tabular}{lllllll}
\hline \multirow{2}{*}{ Element } & $\mathrm{N}$ & \multicolumn{2}{l}{ Summer faeces } & & \multicolumn{2}{l}{ Winter faeces } \\
\cline { 7 - 7 } \cline { 6 - 7 } & & Average & $\mathrm{SD}$ & & Average & $\mathrm{SD}$ \\
\hline $\mathrm{Cr}$ & 15 & 0.012 & 0.009 & 0.02 & 0.006 \\
$\mathrm{Mn}$ & 15 & 0.698 & 0.378 & 0.454 & 0.125 \\
$\mathrm{Fe}$ & 15 & 9.51 & 6.15 & 14.9 & 4.52 \\
$\mathrm{Ni}$ & 15 & 0.029 & 0.018 & 0.018 & 0.004 \\
$\mathrm{Cu}$ & 15 & 0.074 & 0.061 & 0.072 & 0.064 \\
$\mathrm{Zn}$ & 15 & 0.371 & 0.225 & 0.198 & 0.056 \\
$\mathrm{Cd}$ & 15 & 0.003 & 0.002 & 0.001 & 0.001 \\
$\mathrm{~Pb}$ & 15 & 0.006 & 0.003 & 0.008 & 0.004 \\
\hline
\end{tabular}

elements in animal tissue after forage digestion as they are excreted in faeces. Nevertheless, the concentrations of heavy metals in the faeces were low compared with those in vascular plants, bryophytes and lichens grazed by the reindeer, and their content in reindeer tissue (Fig. 2; Table 3).

Although the statistical analysis showed significant differences between summer and winter excrement in terms of the concentrations of the selected heavy metals, it is difficult to draw any unequivocal conclusions on this issue since no other data on the content of elements in reindeer excrement in the Arctic region exist. Furthermore, it is worth underlining the fact that, compared to Norwegian reindeer, Svalbard reindeer are a different subspecies which subsist in different habitat conditions that influence the microbial structure of reindeer rumen (Sundset et al. 2007). The only study on the abovementioned topic was conducted in 1979 in Adventdalen, where six faecal samples were collected from the distal colon of reindeer shot in the field (Staaland et al. 1983) that showed differences between concentrations of $\mathrm{Fe}, \mathrm{Cu}, \mathrm{Mn}$, and $\mathrm{Zn}$ in summer and winter excrement. When we compare this study with our own results, we can observe that the average heavy metal content in faecal samples from 1979 is much higher (Table 3). These concentrations are also much higher when compared with reindeer tissue and examined vegetation (Table 3), and it is difficult to compare these values with the obtained results.

The results can be analysed in terms of reindeer dietary preferences during the Arctic year, the form of available forage probably influencing the heavy metal content in summer and winter faeces (Figs 2 and 3; Table 3). Differences in the percentages of herbaceous plants, shrubs, bryophytes and lichens eaten by reindeer during the summer and winter (Bjørkvoll et al. 2009; Ekern and Kildemo 1987; Staaland et al. 1993), as well as different contents of particular element in such vegetation (Table 2; Wojtuń et al. 2013), are probably a major reason for variations in heavy metal content, both in reindeer tissue (Borch-Iohnsen et al. 1996) and in excrement.
The mesic tundra of the study area is dominated by dwarf shrubs, flowering plants and graminoids, while bryophytes and lichens were less common (Table S1). According to Elvebakk (2005), the vegetation of Bolterdalen is dominated by Cassiope tetragona, which is similar to the vegetation of Colesdalen where the research by Bjørkvoll et al. (2009) was undertaken. In the study conducted by Bjune (2000) in Todalen in the valley parallel to Bolterdalen, the characteristic vegetation was similar to that of Bolterdalen and the area investigated by Staaland et al. (1993) in Broggerhalvoya was dominated by Cassiope tetragona and Luzula nivalis (Elvebakk 2005), which is also similar to that of Bolterdalen. The species composition of mesic tundra has a direct influence on the reindeer's diet, which in turn dictates the heavy metal content in excrement (Fig. 2; Table 2). Flowering plants and graminoids are the most frequently grazed by reindeer during summer (Fig. 3), but graminoids are also commonly eaten during the early winter (Staaland et al. 1993; Bjune 2000; Bjørkvoll et al. 2009). In contrast, dwarf shrubs, bryophytes and lichens are important components of the reindeer's winter diet (Staaland et al. 1993; Bjune 2000; Bjørkvoll et al. 2009). In the summertime, reindeer feed on flower petals, while in winter they eat the ligneous parts of plants (Staaland et al. 1993; Bjune 2000; Bjørkvoll et al. 2009).

The obtained results only partly confirmed the hypothesis that assumed that contents of heavy metals in summer excrement will be lower than in winter excrement. Contents of $\mathrm{Cd}$ were higher in the summer faeces, which may be connected with the easy accumulation of $\mathrm{Cd}$ in the leaves and flowers of vascular plants (Kabata-Pendias 2011). In Svalbard, Wojtuń et al. (2013) claimed that vascular plants accumulated Cd within a range of $0.29-1.08 \mathrm{mg} \mathrm{kg}^{-1}$ (Table 3), but in a previous study by Jóźwik (2000), this figure could reach $8 \mathrm{mg} \mathrm{kg}^{-1}$. However, a lower $\mathrm{Cd}$ content has been observed in lichens, bryophytes, and the ligneous parts of vascular plants (Table 3, Wojtuń et al. 2013), which may explain the differences observed in winter and summer excrement. In comparison to reindeer tissue, the Cd content in vascular plants is rather low (Table 3). However, higher levels of $\mathrm{Cd}$ accumulation were observed in reindeer tissue, mainly in the kidneys, which may be the reason for the lower levels of this element in excrement (Fig. 2).

The $\mathrm{Cr}$ content was higher in winter excrement. According to Kabata-Pendias (2011), the concentration of $\mathrm{Cr}$ is higher in bryophytes than in vascular plants. Reindeer frequently feed on bryophytes during the early winter and winter (Fig. 3), which may directly result in a higher $\mathrm{Cr}$ content in winter faeces. Similarly, the Fe content is also higher in winter excrement, and was also observed to be higher in bryophytes than in vascular plants, and indeed in lichens (Table 3). The higher proportion of bryophytes and lichens in winter forage may directly result in a high $\mathrm{Fe}$ content in winter excrement. However, data are not available on Fe content in reindeer tissue. 
Fig. 2 The U Mann-Whitney test comparing heavy metal content between summer and winter excrement. Significant differences $(p<0.05)$ are marked by $p$ values highlighted in bold
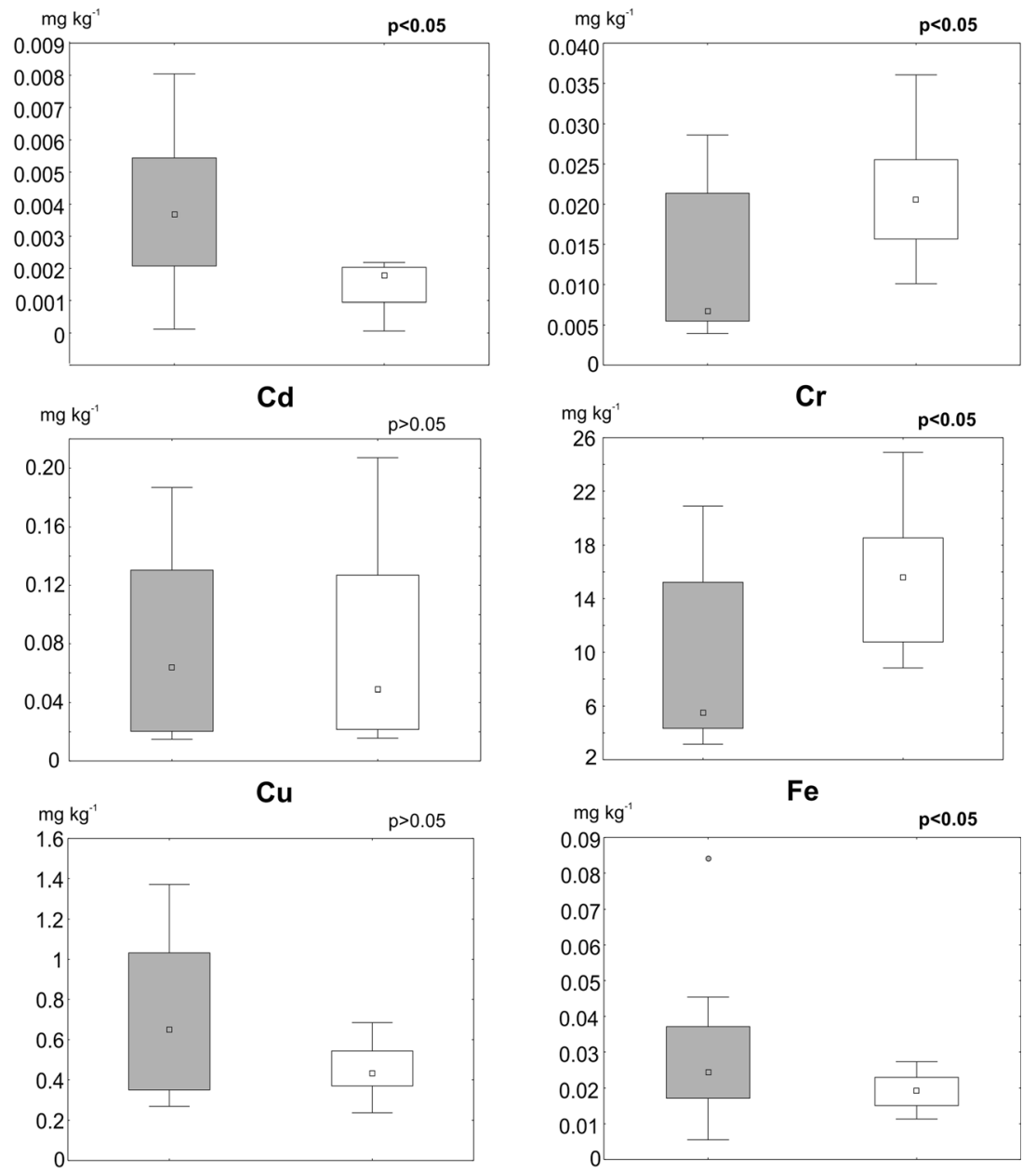

Mn
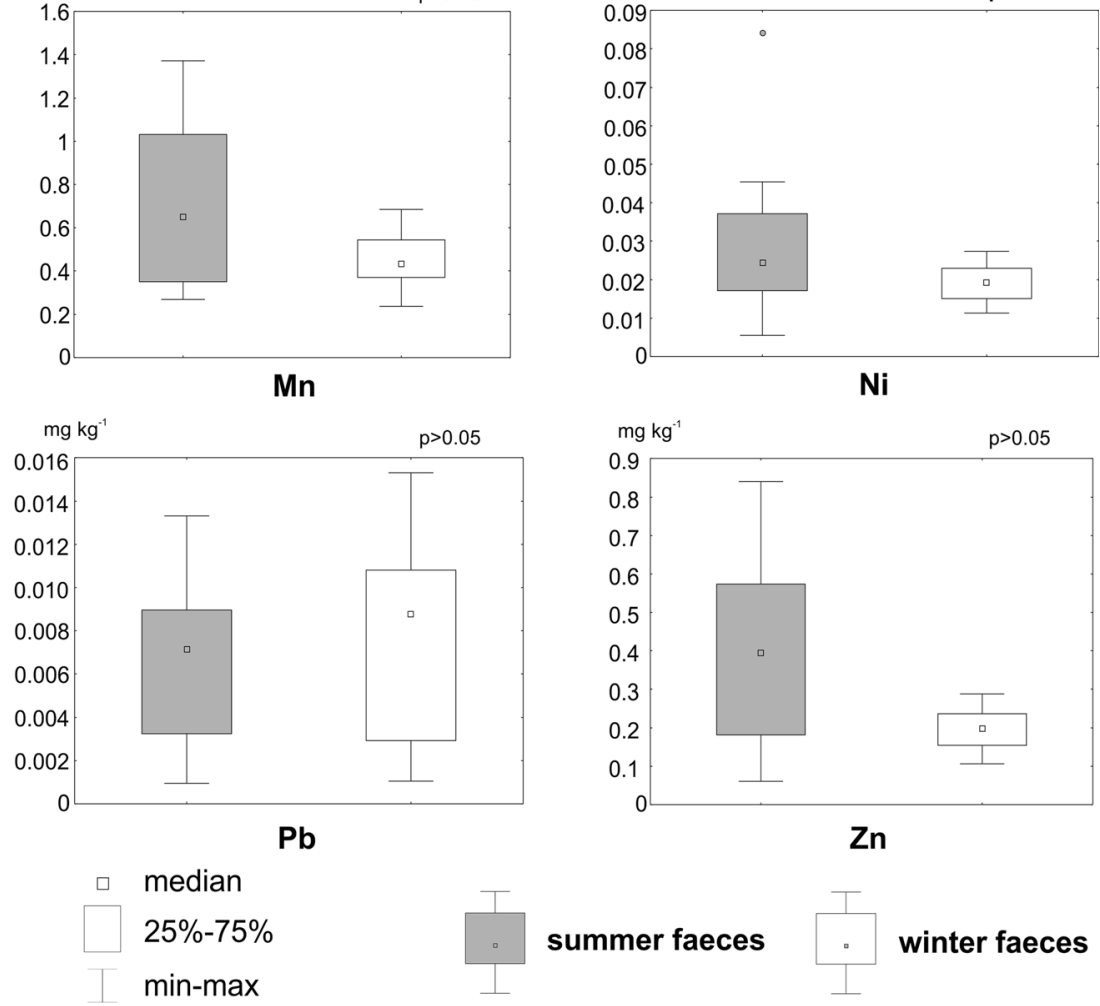

summer faeces
The Mn content seems to be similar in winter and summer excrement (Fig. 2). Mn in vascular plants, the content of which can be metabolically controlled, mainly accumulates in leaves and may reach $121 \mathrm{mg} \mathrm{kg}^{-1}$ (Kabata-Pendias 2011). On the other hand, its concentration in bryophytes can be twice as high as in vascular plants (Table 3). The high proportion of forage consisting of vascular plants in summer and bryophytes in winter, together with the accumulation of
Mn in the liver and kidney, appear to explain its consistent level in excrement across the different seasons. A slightly higher content of $\mathrm{Ni}$ was noted in summer excrement (Fig. 2), which may be due to its high content in the leaves and seeds of graminoids, flowering plants and shrubs (KabataPendias 2011). However, its high content was also noted in bryophytes, which may explain the similar Ni level in the winter excrement. 
Table 3 A comparison of the minimum and maximum content of heavy metals in lichens, bryophytes, vascular plants (Wojtun et al. 2013), the liver, kidney of Svalbard reindeer (Borch-Iohnsen et al. 1996) together with the obtained element contents in all reindeer excrement. Also the average element contents in faecal samples from distal colon of Svalbard reindeer are given (Staaland et al. 1983)

\begin{tabular}{|c|c|c|c|c|c|c|c|c|c|}
\hline \multirow[t]{2}{*}{ Heavy metal } & & \multicolumn{6}{|c|}{ Minimum and maximum element content $\left[\mathrm{mg} \mathrm{kg}^{-1}\right]$} & \multicolumn{2}{|c|}{ Average element content $\left[\mathrm{mg} \mathrm{kg}^{-1}\right]$} \\
\hline & & Lichens & Bryophytes & Vascular plants & Liver & Kidney & Reindeer faeces & Distal colon & \\
\hline \multirow[t]{2}{*}{$\mathrm{Cd}$} & Min & 0.06 & 0.15 & 0.29 & 0.20 & 0.50 & 0.001 & & - \\
\hline & Max & 0.10 & 0.51 & 1.08 & 2.40 & 23.0 & 0.008 & & - \\
\hline \multirow[t]{2}{*}{$\mathrm{Cr}$} & Min & 0.27 & 2.28 & 0.38 & - & - & 0.004 & & - \\
\hline & Max & 0.83 & 8.49 & 1.12 & - & - & 0.036 & & - \\
\hline \multirow[t]{2}{*}{$\mathrm{Cu}$} & Min & 0.77 & 4.85 & 2.20 & 3.20 & 2.20 & 0.015 & Summer & 26 \\
\hline & Max & 1.33 & 13.50 & 6.00 & 260 & 7.60 & 0.207 & Winter & 11.1 \\
\hline \multirow[t]{2}{*}{$\mathrm{Fe}$} & Min & 357 & 1,97 & 120 & - & - & 3.15 & Summer & 4.39 \\
\hline & Max & 629 & 7,11 & 353 & - & - & 24.9 & Winter & 15.69 \\
\hline \multirow[t]{2}{*}{$\mathrm{Mn}$} & Min & 12.0 & 77.38 & 47.6 & 1.20 & 0.40 & 0.237 & Summer & 623 \\
\hline & Max & 18.3 & 298 & 121 & 6.50 & 2.50 & 1.37 & Winter & 267 \\
\hline \multirow[t]{2}{*}{$\mathrm{Ni}$} & Min & 0.47 & 1.74 & 0.60 & - & - & 0.005 & & - \\
\hline & Max & 0.90 & 6.89 & 2.14 & - & - & 0.084 & & - \\
\hline \multirow[t]{2}{*}{$\mathrm{Pb}$} & Min & 1.77 & 1.49 & 0.48 & 0.50 & 0.60 & 0.001 & & - \\
\hline & Max & 2.53 & 9.95 & 1.38 & 6.10 & 15.0 & 0.015 & & - \\
\hline \multirow[t]{2}{*}{$\mathrm{Zn}$} & Min & 11.0 & 19.5 & 34.20 & 15.0 & 15.0 & 0.061 & Summer & 545 \\
\hline & Max & 16.3 & 33.4 & 65.60 & 140 & 38.0 & 0.839 & Winter & 148 \\
\hline
\end{tabular}

There was no difference in $\mathrm{Pb}$ content between the summer and winter excrement (Fig. 2). This element accumulates similar levels in both vascular plants and cryptogams (Table 3). The high content of $\mathrm{Pb}$ in reindeer kidneys and livers might be a factor influencing its content in faeces (Table 3). The difference in $\mathrm{Zn}$ content between summer and winter excrement has not been confirmed by statistical analysis (Fig. 2). As with $\mathrm{Pb}$, this element has accumulated at high levels in reindeer livers

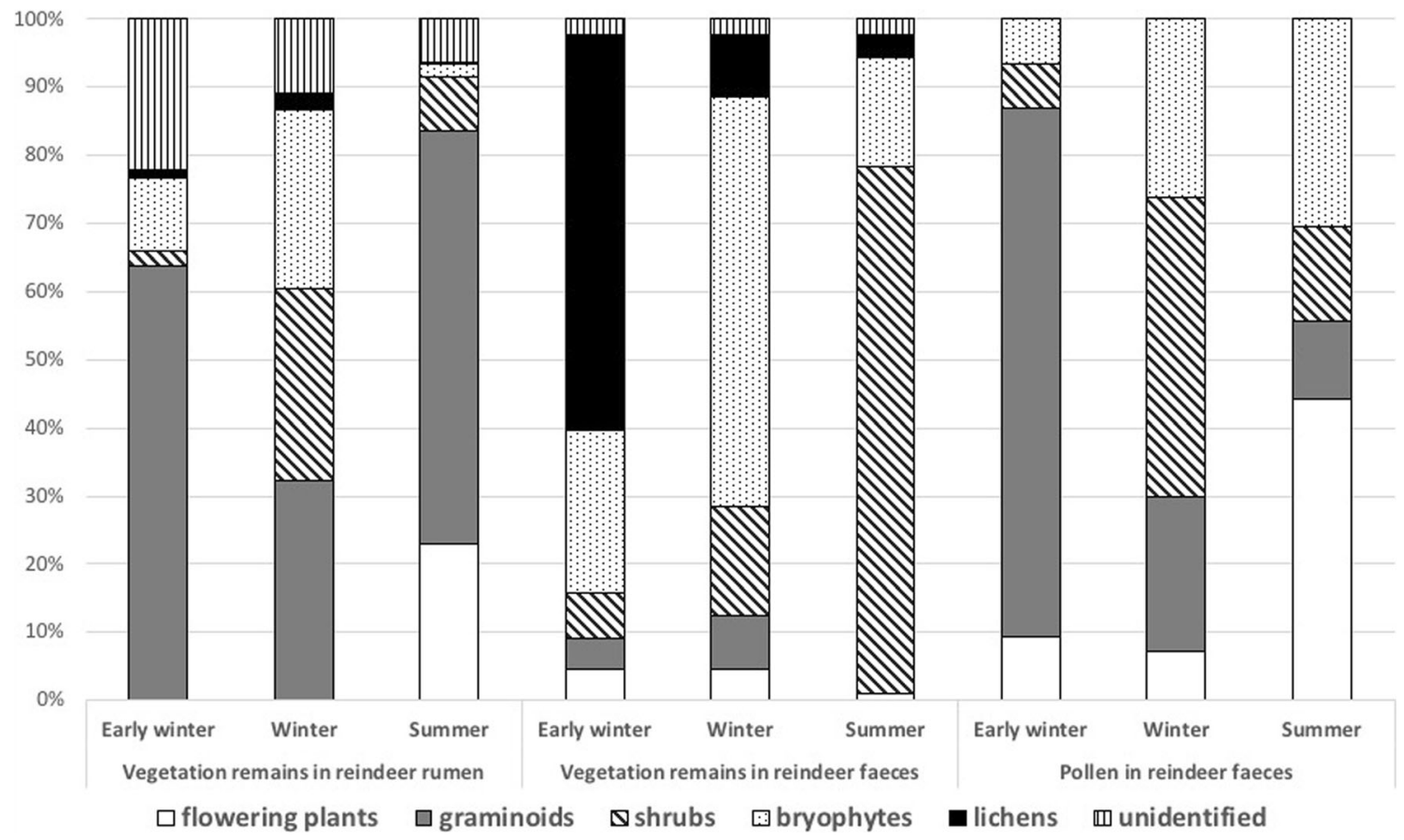

Fig. 3 Differences in the percentage composition of reindeer diet in the early winter, winter and summer, based on the species remains investigated in reindeer rumen from a reindeer population in Colesdalen in 1999-2002 (Bjørkvoll et al. 2009) and species remains investigated in reindeer faeces collected in Broggerhalvoya in 1989 (Staaland et al. 1993) and based on the pollen investigated in reindeer faeces collected in Todalen in 1994-1995 (Bjune 2000) 
and kidneys, and this may have an indirect influence on its content in faeces.

Analysing the heavy metal contents in vegetation and in animals fed upon it, the local sources of contamination also play an important role. As regards Borteldalen, situated c. $300 \mathrm{~m}$ above the valley, the coal dust which is emitted from the still active Gruve 7 coal mine may affect the content of heavy metals in vegetation grazed by reindeer, and may be deposited on the surface of faeces. The conducted studies (e.g. Pandey et al. 2014) showed that coal dust may influence the content of heavy metals, but in Svalbard there has been no detailed investigation of its deposition and impact on both vegetation and animals. Due to the fact that from the second half of the twentieth century Norwegian coal mines have been successively closed, further comparative analyses of heavy metal content will allow the scale of future pollutant changes to be estimated.

\section{Conclusions}

Despite its preliminary character, the research investigated the heavy metals in reindeer excrement. Differences in the concentration of heavy metals in winter and summer excrement would appear to be as a consequence of the variability of reindeer forage during the year, as well as possibly being influenced by their accumulation in reindeer tissue. The presented study is a starting point for future research on heavy metal contents and non-invasive monitoring of pollutants in Arctic ecosystems.

Acknowledgements We would like to thank Professor Monica A. Sundset (Department of Arctic and Marine Biology, University of Tromsø - The Arctic University of Norway) for her helpful criticism of an earlier draft of this contribution. We would like to thank Professor Mark Seaward (Department of Archaeological and Environmental Science, University of Bradford) for his linguistic corrections and valuable remarks. We are also grateful to anonymous reviewers for their suggestions and remarks on our manuscript.

Funding information The contribution made by Paulina Wietrzyk received financial support from the statutory fund of the Institute of Botany of the Jagiellonian University (K/DSC/004623). The work of Beata Cykowska-Marzencka was supported by the statutory fund of the W. Szafer Institute of Botany of the Polish Academy of Sciences.

Open Access This article is distributed under the terms of the Creative Commons Attribution 4.0 International License (http:// creativecommons.org/licenses/by/4.0/), which permits unrestricted use, distribution, and reproduction in any medium, provided you give appropriate credit to the original author(s) and the source, provide a link to the Creative Commons license, and indicate if changes were made.

\section{References}

Aastrup P, Riget F, Dietz R, Asmund G (2000) Lead, zinc, cadmium, mercury, selenium and copper in Greenland caribou and reindeer
(Rangifer tarandus). Sci Total Environ 245:149-159. https://doi. org/10.1016/S0048-9697(99)00440-4

AMAP (2005) AMAP assessment 2002: heavy metals in the Arctic. In: Arctic monitoring and assessment programme, Oslo

Austrheim G, Hassel K, Mysterud A (2005) The role of life history traits for bryophyte community patterns in two contrasting alpine regions. Bryologist 108(2):259-271. https://doi.org/10.1639/00072745(2005)108[0259:TROLHT]2.0.CO;2

Bjørkvoll E, Pedersen B, Hytteborn H, Jónsdóttir IS, Langvatn R (2009) Seasonal and interannual dietary variation during winter in female Svalbard reindeer (Rangifer tarandus platyrhynchus). Arct Antarct Alp Res 41:88-96. https://doi.org/10.1657/1523-0430-41.1.88

Bjune AE (2000) Pollen analysis of faeces as a method of demonstrating seasonal variations in the diet of Svalbard reindeer (Rangifer tarandus platyrhynchus). Polar Res 19:183-192

Borch-Iohnsen B, Nilssen KJ, Norheim G (1996) Influence of season and diet on liver and kidney content of essential elements and heavy metals in Svalbard reindeer. Biol Trace Elem Res 51:235-247. https://doi.org/10.1007/BF02784078

Braun-Blanquet J (1964) Pflanzensoziologie. Grundzuge der Vegetationskunde. Springer-Verlag, Wien

Clarkson TW (1986) Effects: general principles underlying the toxic action of metals. In: Friberg L, Nordberg G, Vouk V (eds) Handbook on the toxicology of metals. Elsevier, Amsterdam, pp 128-148

Drbal K, Elster J, Komarek J (1992) Heavy metals in water ice and biological material from Spitsbergen Svalbard. Polar Res 11:99-101

Ekern K, Kildemo K (1987) Svalbardreinens ernæring. Hovedoppgave, Institutt for Naturforvaltning, Norges Landbrukshøyskole, As

Elvebakk A (2005) A vegetation map of Svalbard on the scale 1:3.5 mill. Phytocoenologia 35(4):951-967. https://doi.org/10.1127/0340269X/2005/0035-0951

Garty J (2001) Biomonitoring atmospheric heavy metals with lichens: theory and application. Crit Rev Plant Sci 20:309-371. https://doi. org/10.1080/20013591099254

Hallanger IG, Warner NA, Ruus A, Evenset A, Christensen G, Herzke D, Gabrielsen GW, Borgå K (2011) Seasonality in contaminant accumulation in Arctic marine pelagic food webs using trophic magnification factor as a measure of bioaccumulation. Environ Toxicol Chem 30:1026-1035. https://doi.org/10.1002/etc.488

Hansen BB, Aanes R, Sæther B-E (2010) Partial seasonal migration in high-arctic Svalbard reindeer (Rangifer tarandus platyrhynchus). Can J Zool 88:1202-1209. https://doi.org/10.1139/Z10-086

Jóźwik Z (2000) Heavy metals in tundra plants of the Bellsund in West Spitsbergen, investigated in the years 1987-1995. Pol Polar Res 21: $43-54$

Kabata-Pendias A (2011) References. In: Trace elements in soils and plants. CRC Press, Boca Raton. https://doi.org/10.1201/b10158-25

Koivurova T (2005) Environmental protection in the Arctic and Antarctic: can the polar regimes learn from each other? Int J Leg Inf 33(2):204-218

Larter NC, Nagy JA (2000) A comparison of heavy metal levels in the kidneys of high Arctic and mainland caribou populations in the Northwest Territories of Canada. Sci Total Environ 246:109-119. https://doi.org/10.1016/S0048-9697(99)00418-0

Lyså A, Lnne I (2001) Moraine development at a small high-Arctic valley glacier: Rieperbreen, Svalbard. J Quat Sci 16:519-529. https://doi. org/10.1002/jqs.613

Na G, Wei W, Zhou S, Gao H, Ma X, Qiu L, Ge L, Bao C, Yao Z (2015) Distribution characteristics and indicator significance of Dechloranes in multi-matrices at Ny-Alesund in the Arctic. J Environ Sci (China) 28:8-13. https://doi.org/10.1016/j.jes.2014.07.019

National Research Council (1980) Mineral tolerance of domestic animals. National Academy of Science, Washington, DC

Norwegian Polar Institute (2016) Norwegian Polar Institute Map Data and Services. Norwegian Polar Institute. https://geodata.npolar.no/. Accessed 21 March 2018 
Nriagu J (1979) Global inventory of natural and anthropogenic emissions of trace metals to the atmosphere. Nature 279(5712):409-411

Nriagu J (1989) A global assessment of natural sources of atmospheric trace metals. Nature 338(6210):47-49

Olech M, Wegrzyn M, Lisowska M, Słaby A, Angiel P (2011) Contemporary changes in vegetation of polar regions. Papers on Global Change IGBP 18:35-51. https://doi.org/10.2478/v10190010-0003-8

Pandey B, Agrawal M, Singh S (2014) Assessment of air pollution around coal mining area: emphasizing on spatial distributions, seasonal variations and heavy metals, using cluster and principal component analysis. Atmos Pollut Res 5(1):79-86

Reimers E (1982) Winter mortality and population trends of reindeer on Svalbard, Norway. Arct Alp Res 14:295-300

Ruman M, Kozak K, Lehmann S, Koziol K, Polkowska Z (2012) Pollutants present in different components of the Svalbard archipelago environment. Ecol Chem Eng S 19:571-584. https://doi.org/10. 2478/v10216-011-0040-9

Samecka-Cymerman A, Wojtuń B, Kolon K, Kempers AJ (2011) Sanionia uncinata (Hedw.) loeske as bioindicator of metal pollution in polar regions. Polar Biol 34:381-388. https://doi.org/10.1007/ s00300-010-0893-X

Sancho LG, Green TA, Pintado A (2007) Slowest to fastest: extreme range in lichen growth rates supports their use as an indicator of climate change in Antarctica. Flora 202(8):667-673

Simões JC, Zagorodnov VS (2001) The record of anthropogenic pollution in snow and ice in Svalbard, Norway. Atmos Environ 35(2): 403-413. https://doi.org/10.1016/S1352-2310(00)00122-9

Staaland H, Brattbakk I, Ekern K, Kildemo K (1983) Chemical composition of reindeer forage plants in Svalbard and Norway. Ecography 6:109-122. https://doi.org/10.1111/j.1600-0587.1983.tb01072.x

Staaland H, Scheie JO, Grøndahl A, Person E, Leifseth AB, Holand Ø (1993) The introduction of reindeer to Brøggerhalvøya, Svalbard: grazing preference and effect on vegetation. Rangifer 13:15-19

Steinnes E (1995) A critical evaluation of the use of naturally growing moss to monitor the deposition of atmospheric metals. Sci Total Environ 160:243-249. https://doi.org/10.1016/0048-9697(95) 04360-D

Stoltz E, Greger M (2002) Accumulation properties of As, Cd, Cu, Pb and $\mathrm{Zn}$ by four wetland plant species growing on submerged mine tailings. Environ Exp Bot 47(3):271-280. https://doi.org/10.1016/ S0098-8472(02)00002-3

Sundset MA, Præsteng KE, Cann IKO, Mathiesen SD, MacKie RI (2007) Novel rumen bacterial diversity in two geographically separated sub-species of reindeer. Microb Ecol 54:424-438. https://doi.org/ 10.1007/s00248-007-9254-x

Tyler NJC (1986) The relationship between the fat content of Svalbard reindeer in autumn and their death from starvation in winter. Rangifer 6:311-314

Tyler N, Øritsland N (1989) Why don't Svalbard reindeer migrate? Holarct Ecol 12:369-376

Wang Z, Na G, Ma X, Ge L, Lin Z, Yao Z (2015) Characterizing the distribution of selected PBDEs in soil, moss and reindeer dung at Ny-Alesund of the Arctic. Chemosphere 137:9-13. https://doi.org/ 10.1016/j.chemosphere.2015.04.030

Wegrzyn M, Lisowska M, Nicia P (2013) The value of the terricolous lichen Cetrariella delisei in the biomonitoring of heavy-metal levels in Svalbard. Pol Polar Res 34:375-382. https://doi.org/10.2478/ popore-2013-0022

Wegrzyn M, Wietrzyk P, Lisowska M, Klimek B, Nicia P (2016) What influences heavy metals accumulation in arctic lichen Cetrariella delisei in Svalbard? Polar Sci 10:532-540. https://doi.org/10.1016/ j.polar.2016.10.002

Weinbruch S, Wiesemann D, Ebert M, Schütze K, Kallenborn R, Ström J (2012) Chemical composition and sources of aerosol particles at Zeppelin Mountain (Ny-Ålesund, Svalbard): an electron microscopy study. Atmos Environ 49:142-150. https://doi.org/10.1016/j. atmosenv.2011.12.008

Wojtuń B, Samecka-Cymerman A, Kolon K, Kempers AJ, Skrzypek G (2013) Metals in some dominant vascular plants, mosses, lichens, algae, and the biological soil crust in various types of terrestrial tundra, SW Spitsbergen, Norway. Polar Biol 36:1799-1809. https://doi.org/10.1007/s00300-013-1399-0

Zhang P, Ge L, Gao H, Yao T, Fang X, Zhou C, Na G (2014) Distribution and transfer pattern of polychlorinated biphenyls (PCBs) among the selected environmental media of Ny-Ålesund, the Arctic: as a case study. Mar Pollut Bull 89:267-275. https://doi.org/10.1016/j. marpolbul.2014.09.050

Zhu C, Li Y, Wang P, Chen Z, Ren D, Ssebugere P, Zhang Q, Jiang G (2015) Polychlorinated biphenyls (PCBs) and polybrominated biphenyl ethers (PBDEs) in environmental samples from $\mathrm{Ny}-$ Ålesund and London Island, Svalbard, the Arctic. Chemosphere 126:40-46. https://doi.org/10.1016/j.chemosphere.2015.01.043

Ziaja W, Wegrzyn M, Dudek J, Ostafin K, Lisowska M, Olech M, Osyczka P (2016) Transformation of the natural environment in Western Sørkapp Land (Spitsbergen) since the 1980s. Springer International Publishing, Cham 